\title{
EQUITY CROWDFUNDING SUCCESS: AN EXAMINATION OF TITLE II OFFERINGS
}

\author{
SUZANNE K. HAYES*, BREE L. DORITY**, SARAH J. BORCHERS***
}

\begin{abstract}
Equity crowdfunding (ECF) is a relatively new financing model in the United States (U.S). Many investors and small business owners are exploring this new avenue of capital formation; however, it is a research area that is relatively unexplored due to the limited availability of data. This paper examines factors related to campaign funding success for companies seeking capital under Title II of the JOBS Act. Using a Tobit regression we find that firms which report their equity capitalization raise a higher percentage of their campaign ask. A lower minimum target amount is identified as a second factor related to funding success. This study also shows that firms not reporting a tagline raise a larger percent of their offer, underscoring the importance of quality text descriptions. In addition, we find that economic conditions such as equity market sentiment are important to ECF success.
\end{abstract}

Keywords: equity crowdfunding, JOBS Act, Title II, ECF campaign success

JEL Classification: $G 11, G 10$

\section{INTRODUCTION}

Transforming ideas into new business ventures can be a costly endeavor. In the past, entrepreneurs relied on angel investors and venture capitalists for funding. Crowdfunding is a new form of financing, increasing in use as both a substitute and a complement to angel and venture investments. It has been defined as "an open call, essentially through the Internet, for the provision of financial resources either in form of donation or in exchange for some form of

\footnotetext{
* Suzanne K. Hayes, University of Nebraska-Kearney, 1917 W 24th Street, Kearney, NE 68849 USA, (308) 865-8170, hayessk@unk.edu

** Bree L. Dority, University of Nebraska-Kearney, 1917 W 24th Street, Kearney, NE 68849 USA, (308) 865-8343, doritybl@unk.edu

${ }^{* * *}$ Sarah J. Borchers, University of Nebraska-Kearney, 1917 W 24th Street, Kearney, NE 68849 USA, (308) 865-8108, borcherssj@unk.edu
} 
reward and/or voting rights in order to support initiatives for specific purposes" (Schwienbacher \& Larralde, 2010). Crowdfunding has grown exponentially in the past decade as a new financing mechanism for start-up companies. In 2017 alone, $\$ 17.2$ billion was raised through crowdfunding platforms in North America. This accounts for approximately half of the $\$ 28.8$ billion raised globally (Szmigiera, 2019). Peer-to-peer lending represents the largest portion of the overall crowdfunding market, followed in size by donations/rewards and equity crowdfunding (ECF). Of the total amount raised through crowdfunding globally, approximately $\$ 2.5$ billion was raised via equity crowdfunding campaigns (United States Securities and Exchange Commission [SEC], 2019). Until recently, United States entrepreneurs were not able to gain funding through internet-based ECF. Despite the regulatory hurdles, the U.S. ECF shows early sizable growth. An estimated $\$ 1.4$ billion has been raised by entrepreneurs from accredited investors via equity crowdfunding platforms since the passage of Title II of the JOBS Act in 2013 (Mamonov, Malaga \& Rosenblum, 2017).

Due to prior U.S. regulations, most of the research to date on crowdfunding has been done on countries outside of the U.S., leaving research on equity crowdfunding in the U.S. in its early stages of exploration. To our knowledge, only a handful of studies have been done on equity crowdfunding in the U.S. (Mamonov et al., 2017; Malaga, Mamonov, \& Rosenblum, 2018; Mamonov \& Malaga, 2019(1); Mamonov \& Malaga, 2019(2)). These projects provide descriptive statistics (Malega et al, 2018) or focus on specific portions of U.S. ECF such as real estate (Mamonov et al, 2017) or use relatively small samples (Mamonov \& Malaga, 2019(1); Mamonov \& Malaga, 2019(2)).

In this paper, we conduct the first in-depth analysis of Title II ECF in the US by exploring the determinants of success for more than 3,200 Title II crowdfunding campaigns across 12 intermediary platforms. Our analysis reveals the importance of equity market conditions and company factors such as prior market capitalization and taglines. The results have both academic and industry applications. Our study advances the nascent research stream on U.S. equity crowdfunding and discovers information important for early-stage entrepreneurs seeking capital under ECF.

We begin the paper with a description of ECF and a review of equity crowdfunding literature. The data and methodology are discussed next, followed by the results section. An overview of future research and a summary conclude the paper. 


\section{Equity CROWDFUnding}

\subsection{DESCRIPTION AND LEGISLATIVE BASIS}

Although equity crowdfunding has been established in other countries for over a decade, until recently, ECF was not an option in the U.S. Currently, under federal securities law, there are three primary options available in the U.S. for firms seeking capital from the crowd. Companies may select from Regulation A+; Title II, Regulation D Rule 506(c); and Title III of the JOBS Act, Regulation Crowdfunding. These options are summarized in Table 1.

Table 1. Crowdfunding Options in the United States

\begin{tabular}{|c|c|c|c|}
\hline & $\begin{array}{c}\text { Regulation D, Rule } \\
506(c)\end{array}$ & Regulation A+ & Regulation Crowdfunding \\
\hline Title of the JOBS Act & Title II & Title IV & Title III \\
\hline Effective Date & September 23, 2013 & June 19, 2015 & May 16, 2016 \\
\hline Investors Allowed & \begin{tabular}{|l} 
Accredited investors \\
only \\
See also note $[\mathrm{A}]$ \\
\end{tabular} & $\begin{array}{l}\text { Accredited and non- } \\
\text { accredited investors }\end{array}$ & $\begin{array}{l}\text { Accredited and non-accredited } \\
\text { investors }\end{array}$ \\
\hline $\begin{array}{l}\text { Marketing of } \\
\text { Securities }\end{array}$ & General solicitation & General solicitation & $\begin{array}{l}\text { Limited to a brief notice if } \\
\text { advertising off of the } \\
\text { intermediary's platform. } \\
\text { Can communicate with } \\
\text { investors and potential } \\
\text { investors about the terms of } \\
\text { the offering through } \\
\text { communication channels } \\
\text { provided on the intermediary's } \\
\text { platform. }\end{array}$ \\
\hline Security Type & Restricted & Unrestricted & Generally restricted \\
\hline Offering Limit & None & $\begin{array}{l}\text { Tier I: limit of } \$ 20 \text { million } \\
\text { within a } 12 \text {-month period } \\
\text { Tier II: limit of } \$ 50 \text { million } \\
\text { within a } 12 \text {-month period } \\
\end{array}$ & $\begin{array}{l}\$ 1.07 \text { million within a } 12- \\
\text { month period } \\
\text { See also note }[\mathrm{B}]\end{array}$ \\
\hline $\begin{array}{l}\text { Review } \\
\text { Requirements }\end{array}$ & None & $\begin{array}{l}\text { Tier I: SEC and state-level } \\
\text { review } \\
\text { Tier II: SEC }\end{array}$ & $\begin{array}{l}\text { Disclosure by issuers is } \\
\text { required (Form C) }\end{array}$ \\
\hline $\begin{array}{l}\text { Ongoing Reporting } \\
\text { Requirements }\end{array}$ & None & $\begin{array}{l}\text { Tier I: None } \\
\text { Tier II: Semiannual and } \\
\text { annual reports with the } \\
\text { SEC after the offering }\end{array}$ & $\begin{array}{l}\text { Progress updates (Form C-U) } \\
\text { and annual reports (Form C- } \\
\text { AR) }\end{array}$ \\
\hline
\end{tabular}


[A] An individual "accredited investor" has: (1) A minimum of $\$ 200,000$ in earned income $(\$ 300,000$ when combined with a spouse) in each of the two prior years and a "reasonable expectation" of a repeat in the current year, or (2) \$1 million or more in net worth, not including primary residence.

[B] There are also limits on the amount individual investors can invest across all crowdfunding offerings in a 12-month periods: (1) If investor's annual income or net worth is less than $\$ 100,000$, the limit is the greater of: (a) $\$ 2,000$ or (b) 5 percent of the lesser of their annual income or net worth, (2) If an investor's annual income and net worth are equal to or more than $\$ 100,000$, the limit is 10 percent of the lesser of their annual income or net worth, and (3) During the 12-month period, the aggregate amount of securities sold to an investor through all crowdfunding offerings may not exceed $\$ 100,000$.

Source: U.S. Securities and Exchange Commission

The effective date of Title II of the JOBS Act is September 23, 2013. This legislation repealed the ban on general solicitation of securities offerings to accredited investors. Rule 506(c), Regulation D, allows advertising and marketing of securities, with no limit on the amount of the offer, to accredited investors only. Issuers are required to verify the accredited status, either individually or through the intermediary. Individuals may be classified as accredited investors if at least one of the following criteria is satisfied. First, an individual alone, or jointly with a spouse, must show a net worth of $\$ 1$ million at the time of the security purchase. Net worth is calculated independent of the primary residence value and related debt. Accredited status may also be achieved with income. Individuals with income over $\$ 200,000$ in each of the preceding two years, or income jointly with a spouse of at least $\$ 300,000$, may qualify as accredited, provided there is a reasonable expectation that the income level(s) will continue during the current year (SEC, 2016).

In 2015, the JOBS Act was expanded to include Title IV, Regulation A+. This provision expands the investor base to include non-accredited investors and introduced offer limits. Under Reg A+ issuers may raise up to $\$ 50$ million. Offerings under Tier I have a limit of \$20 million within a 12 month period and investors are not limited in their commitments. Tier II offers allow up to $\$ 50$ million, in a 12 month period, with investor commitment limits. Issuers may advertise and face no limits on the type of investor solicited (SEC, 2016).

Title III of the JOBS Act, Regulation Crowdfunding, also allows ECF participation by non-accredited investors and imposes individual investor commitment limits. Firms may solicit up to $\$ 1.07$ million via ECF over a 12 month time period under this provision with an effective date of May 16, 2016. This amount is subject to inflation adjustments by the SEC on a five year basis. Offers must be conducted through an intermediary operating as either a broker-dealer or 
funding portal that is registered with the SEC and Financial Industry Regulatory Authority (SEC, 2016).

\subsection{LiterATURE REVIEW}

The financial crisis of 2007-08 led to a constricted capital supply and difficult conditions for early - mid stage startup firms. The JOBS Act relaxed the rules for pubic solicitation of funds and provided exemptions from costly SEC registration. This Act aimed to stimulate economic growth by improving access to public capital markets. Because equity crowdfunding has many similarities to venture capital and angel investing such as motives for investing, funding through shares, and an absence of active intermediaries, it is beginning to provide an additional source of funding for entrepreneurs (Lukkarinen, Teich, Wallenius, \& Wallenius, 2016).

Funding success is arguably the most widely researched area in ECF and the equity crowdfunding success literature can be broken down into three distinct categories of characteristics: campaign characteristics, networks, and understandability of the company's concept and offering. Campaign characteristics include factors such as the funding target, the minimum investment required, the length of the campaign, and the availability of financial statements (Lukkarinen et al., 2016). Typically, a campaign is set up with a target amount of funding. Prior literature shows that the lower the funding goal and/or the lower the minimum investment required, the higher the probability of success (Block, Hornuf, \& Moritz, 2018; Cordova, Dolci, \& Gianfrate, 2015; Lukkarinen et al., 2016). Further, entrepreneurs who sold a smaller fraction of their companies at listing and had more social capital, experienced a higher likelihood of success (Vismara, 2016). Like funding amounts influence a campaign's success, the length of the campaign also impacts the probability of success where campaign success is more probable in shorter durations. Results indicate contributions are highest in both the beginning of the campaign and also the end. This suggests that the middle, inactive stage of the campaign should be shortened for increased success (Cordova et al., 2015; Harkonen, 2014).

Along the lines of campaign characteristics and success, there is a small stream of literature on the effects of gender on success. Malaga et al. (2018) studied the impact of gender on crowdfunding campaigns in the U.S. Their findings suggest women entrepreneurs are underrepresented in equity crowdfunding platforms as compared to their participation through angel investments, suggesting there is potential for womenowned companies to raise capital via equity crowdfunding platforms. Further, in a United Kingdom-based study, in both rewards-based studies and equity-based studies, 
although women are underrepresented on crowdfunding platforms, they experience higher success rates in fundraising (Horvat \& Papamarkou, 2017).

In previous literature, success is most frequently defined as the venture's ability to attract greater than or equal to their minimum funding target (Colombo, Franzoni, \& Rossi-Lamastra, 2015; Horvat et al., 2017; Malaga et al., 2018; Mamonov et al., 2017; Yan, 2015;). However, other measures of success have included the number of investors attracted, the percentage of the capital campaign raised, or the amount of capital pledged during a campaign on a given day (Block et al., 2018; Colombo et al. 2015; Vismara, 2016).

\section{DATA \& METHODS}

\subsection{Data}

This paper examines data on business equity offerings under Regulation D, Rule 506(c). The dataset covers 506(c) offerings from private businesses seeking public funding from accredited investors. Data is from the inception of Title II of the JOBS Act on September 23, 2013 through September 23, 2016. Equity data is provided by Crowdnetic Corporation. The following intermediaries are included in the dataset: Alchemy Global, AngelList, Crowdfunder, EarlyShares, EquityNet, MicroVentures, OneVest, OurCrowd, Return on Change, Seed Equity, SeedInvest, and WeFunder. This research is based on 3,222 equity offerings with a closed status. Open equity offerings and those with incomplete information are removed from the sample.

\subsection{Model}

To examine factors that are related to successful equity-based crowdfunding, we estimate equations of the following form:

$$
\begin{aligned}
p_{-} \text {raised }= & \beta_{0}+\beta_{1}(\text { Company })+\beta_{2}(\text { Market })+\beta_{3}(\text { Region })+ \\
& \beta_{4}(\text { Sector })+\beta_{5}(\text { time })+\varepsilon \quad \text { (1) }
\end{aligned}
$$

The dependent variable, p_raised, is the percent of the minimum target amount sought that was raised. We use the percent raised rather than a 0-1 variable for the total amount raised because it is rare for a project to raise 100 percent of the funds via equity-based crowdfunding in the U.S. That is, in our sample only 2.0 percent of companies successfully raised 100 percent or more of the funds they sought. This differs from efforts made to raise capital via loan-based crowdfunding. Hayes (2017) examined factors related to successful loan-based 
crowdfunding and overall 16 percent of her sample raised 100 percent or more via loan-based crowdfunding, and Mamonov et al. (2017) focused specifically on real estate lending where the success rate was 88 percent.

Also, a nontrivial number of companies raise 0 percent of the funds sought via equity-based crowdfunding. Thus, given the percent raised distribution is spread out over the range of percentages from 0 to over 100 percent but piles up at the value 0 , we use a Tobit model to estimate equation (1). The Tobit model is designed to model corner solution dependent variables and produces consistent coefficient estimates (Wooldridge, 2002). Finally, when obtaining the error covariances, we cluster by sector to allow for unobserved effects within industry sectors.

The vector of company-specific variables (Company) is limited to what is provided by Crowdnetic Corporation. The dataset captures the minimum target amount sought by the company, whether the company is owned/managed by a woman, whether the equity capital position is reported by the company, and whether the company used a tagline to help inform investors about the company. Prior research shows that (1) the lower the minimum target amount is, the higher is the probability of successful funding (Block et al., 2018; Cordova et al., 2015, Lukkarinen et al., 2016,); and (2) women entrepreneurs tend to be underrepresented in equity crowdfunding platforms (Malaga et al., 2018) but have experienced higher success rates on UK-based equity crowdfunding platforms (Horvat et al., 2017). Prior equity capitalization is a proxy for firm age as companies reporting relatively sizable capitalization levels have likely been in business for a period of time before making the current equity offering. A tagline is a short description of the company's project and indicates that more information is provided to investors.

The vector of market related factors (Market) captures standard indicators of economic activity and market sentiment and includes the monthly percentage change in the consumer price index, the monthly return on the S\&P 500 index, and the average monthly Chicago Board Options Exchange Volatility Index (VIX) value. The VIX is often referred to as the fear index with higher values indicating times of greater uncertainty. We also control for the geographic region of the company location and the sector in which a company operates. Overall, companies are located in 49 states plus Washington D.C. and Puerto Rico (none are in Alaska), and in all eight sectors. Finally, we control for time effects with a quarteryear trend. When Title II of the JOBS Act became effective in the third quarter of 2013, companies rushed to seek funds from accredited investors; however, this tapered over the years as relatively few Title II equity crowdfunding campaigns resulted in a fully financed project. 


\section{RESULTS}

\subsection{Descriptive Analysis}

Definitions, means, and standard deviations for all variables included in the Tobit regressions appear in Table 2.

Table 2. Definitions, Means, Standard Deviations

\begin{tabular}{|c|c|c|c|}
\hline Variable & Definition & Mean & $\begin{array}{c}\text { Std. } \\
\text { Dev. }\end{array}$ \\
\hline p_raise & $\begin{array}{l}\text { Amount of total commitment relative to target amount } \\
(\%)\end{array}$ & 535 & 3.6245 \\
\hline \multicolumn{4}{|c|}{ Independent Variables } \\
\hline issuea & Target amount ( & 3160 & 39.3232 \\
\hline d & $0-1$ if company is owned by a woman & 0.1713 & 0.3768 \\
\hline w_mngt & $\begin{array}{l}0-1 \text { if company is managed by a woman } \\
0-1 \text { if prior equity capitalization is reported by the }\end{array}$ & 0.1853 & 0.3886 \\
\hline r_equcap & company & 0.6356 & 0.4813 \\
\hline tagline & $0-1$ if company used a tagline & 0.8849 & 0.3192 \\
\hline chgcpi & Monthly percentage change in the consumer price index & 0.0001 & 0.3073 \\
\hline sp500 & Monthly return on the S\&P 500 Index & 2.2610 & 2.6641 \\
\hline vix & $\begin{array}{l}\text { Average monthly Chicago Board Options Exchange } \\
\text { Volatility Index (VIX) value }\end{array}$ & $\begin{array}{r}14.338 \\
6\end{array}$ & 2.2295 \\
\hline
\end{tabular}

Sample size is 3,222 .

On average, companies raised 8.0 percent of the minimum target amount and sought to raise a minimum amount of $\$ 2.3$ million. About 17 percent of the companies are owned by a woman and about 19 percent are managed by a woman. Also, about 64 percent of the companies report their prior equity capital level and 88 percent use a company tagline. On average, over the time period examined from 2013 to 2016, consumer prices increased 0.0001 percent each month and the monthly return on the S\&P 500 was 2.3 percent per month. The average monthly VIX value was 14.3 but ranged from 11.4 to 28.4 .

Table 3 presents the number of offerings and the average percent raised by U.S. regions, as well as, identifies the top three states within each region who have companies that are the most successful at raising funds. 
Table 3. Title II Equity Offerings, Top 3 States by Region

\begin{tabular}{lrr}
\hline & \multicolumn{1}{c}{$\begin{array}{c}\text { No. of } \\
\text { Offerings }\end{array}$} & $\begin{array}{c}\text { Pvercent } \\
\text { Raised } \\
\text { (\%) }\end{array}$ \\
\hline Midwest & $\mathbf{3 6 2}$ & $\mathbf{6 . 6}$ \\
Iowa & & 12.8 \\
Wisconsin & & 9.6 \\
Ohio & & 8.1 \\
\hline Northeast & $\mathbf{6 7 5}$ & $\mathbf{6 . 7}$ \\
Vermont & & 111.1 \\
Maryland & & 13.9 \\
New Hampshire & & 10.8 \\
\hline South & $\mathbf{8 4 8}$ & 7.1 \\
Puerto Rico & & 37.8 \\
Alabama & & 20.2 \\
Kentucky & & 18.7 \\
\hline West & & $\mathbf{9 . 5}$ \\
New Mexico & $\mathbf{1 , 3 3 7}$ & 21.4 \\
Montana & & 10.6 \\
Nevada & & 10.4 \\
\hline Total & & $\mathbf{8 . 0}$ \\
\hline & &
\end{tabular}

Overall, more offerings occur among companies located in states in the West followed by those in the South. Together, offerings in these two regions comprise slightly more than two-thirds of all the offerings, and California is the state, by far, with the most offerings at 958 or 29.7 percent of all the offerings. The next two states with the most offerings are New York at 385 (11.9 percent of all the offerings) and Texas at 216 (6.7 percent of all the offerings). In terms of the percentage of funds raised, states in the West are also the most successful, raising 9.5 percent of the minimum target amount, on average, and the West is the only region to raise more than the overall average of 8.0 percent. Vermont is the most successful state where, on average, 111.1 percent of funds were raised, followed by Puerto Rico (37.8 percent) and New Mexico (21.4 percent). 
Table 4 shows the number of offerings and the average percent raised by sector.

Table 4. itle II Equity Offerings, by Sector

\begin{tabular}{lrr}
\hline Sector & $\begin{array}{c}\text { No. of } \\
\text { Offeri } \\
\text { ngs }\end{array}$ & $\begin{array}{c}\text { Avg. Percent } \\
\text { Raised (\%) }\end{array}$ \\
\hline Commerce \& Industry & 128 & 8.2 \\
Consumer Goods & 293 & 7.4 \\
Energy & 65 & 15.9 \\
Financial & 206 & 15.8 \\
Healthcare & 130 & 8.8 \\
Materials & 23 & 16.1 \\
Services & 1,293 & 6.6 \\
Technology & 1,084 & 7.4 \\
\hline Total & $\mathbf{3 , 2 2 2}$ & $\mathbf{8 . 0}$ \\
\hline
\end{tabular}

The majority or 73.8 percent of all equity offerings come from companies in the Services and Technology sectors, yet these two sectors are some of the least successful in terms of raising funds, as on average, they only raise 6.6 percent and 7.4 percent of the minimum target amount, respectively. Conversely, at the lower end of the offering spectrum, the Materials and Energy sectors comprises 2.7 percent of all equity offers; however, these two sectors are the most successful sectors raising above average amounts of 16.1 percent and 15.9 percent of the minimum target amount, respectively.

When we drill down into the industries within the sectors, we find that the top 10 of 268 industries comprise 24 percent of all the equity offerings (Table 5, Panel A), and all ten of these industries are in the Services or Technology sectors. 
Table 5. Title II Equity Offerings, by Industry

\begin{tabular}{|c|c|c|c|}
\hline Industry & Sector & $\begin{array}{r}\text { No. of } \\
\text { Offe } \\
\text { rings } \\
\end{array}$ & $\begin{array}{c}\text { Avg. } \\
\text { Per } \\
\text { cen } \\
\text { t } \\
\text { Rai } \\
\text { sed } \\
(\% \\
) \\
\end{array}$ \\
\hline \multicolumn{4}{|l|}{ Panel A: Top 10 Industries by Number of Listings } \\
\hline Social Media & Technology & 223 & 3.8 \\
\hline App Software & Technology & 113 & 6.8 \\
\hline Education K-12 & Services & 78 & 1.8 \\
\hline Digital Media/New Media & Services & 73 & 3.5 \\
\hline Online \& Mobile Gaming & Technology & 54 & 2.9 \\
\hline Social Commerce & Services & 54 & 10.1 \\
\hline Healthcare Information Services & Technology & 47 & 8.9 \\
\hline Entertainment, Other & Services & 44 & 11.4 \\
\hline Music Services & Services & 44 & 6.8 \\
\hline SaaS & Technology & 43 & 11.2 \\
\hline \multicolumn{4}{|l|}{ Panel B: Top 10 Industries by Percent Raised } \\
\hline $\begin{array}{l}\text { Organic Food \& Beverage } \\
\text { Motion Detection \& Movement Sensing }\end{array}$ & & 3 & 80.6 \\
\hline Technology & Technology & 4 & 63.8 \\
\hline Concert/Theater Ticketing & Services & 4 & 54.4 \\
\hline Home Furnishings \& Fixtures & Consumer Goods & 5 & 41.1 \\
\hline Venture Capital & Financial & 15 & 33.2 \\
\hline Education, Other & Services & 6 & 32.1 \\
\hline Wineries \& Distillers & Consumer Goods & 10 & 31.5 \\
\hline Air Delivery \& Freight Services & $\begin{array}{c}\text { Commerce } \quad \& \\
\text { Industry }\end{array}$ & 2 & 30.0 \\
\hline Green Building Materials & Materials & 6 & 29.8 \\
\hline Investments, Other & Financial & 22 & 28.8 \\
\hline Total & & 3,222 & 8.0 \\
\hline
\end{tabular}

The top 2 industries are Social Media and App Software, which are in the Technology sector. Together, they make up 10.4 percent of all offerings but are below average in terms of successfully raising funds at 3.8 percent and 6.8 percent raised, on average, respectively. Conversely, the most successful industries in 
terms of raising funds encompass relatively few offerings (Table 5, Panel B). For example, the most successful industry is Organic Food \& Beverage in the Consumer Goods sector. On average, companies in this industry raised 80.6 percent of the minimum target amount but there was only a total of three equity offerings made. Overall, within the top 10 most successful industries, only two Investments, Other and Venture Capital both within the Financial sector - had companies making more than ten offerings. All the others only made 2-10 offerings. However, the average percent raised for these industries ranges from 29.8 to 80.6 percent, far above the 8.0 percent average.

Figure 1 shows the number of offerings (black line) and the average percent raised (gray bars) by quarter-year from the fourth quarter of 2013 to the third quarter of 2016.

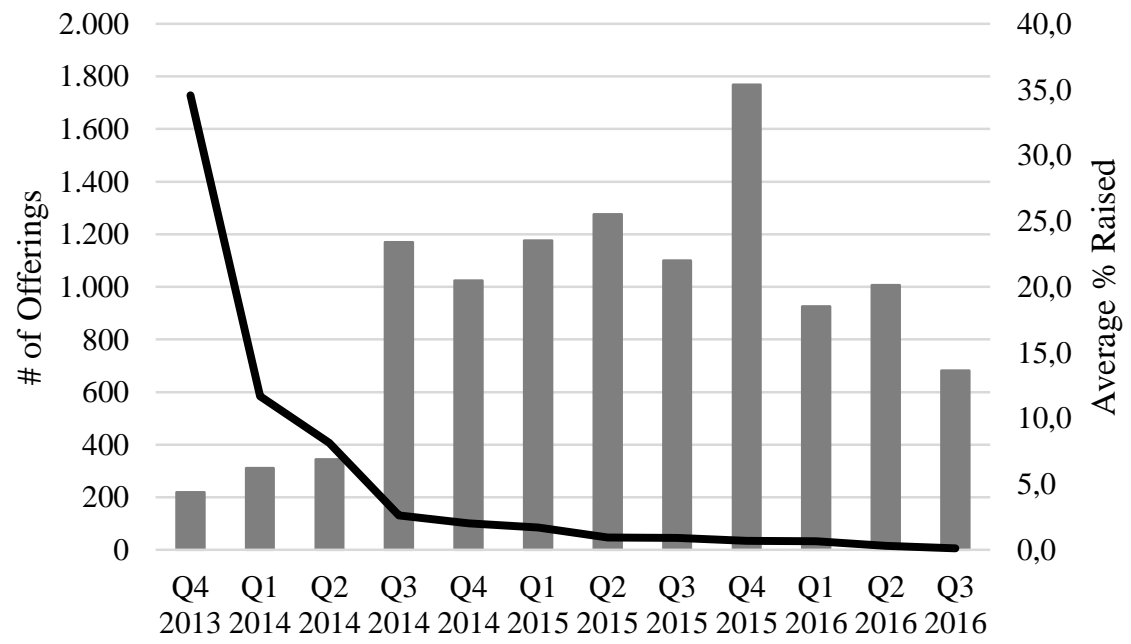

Figure 1. Title II Equity Offerings, by Quarter-Year

More than 80 percent of the offerings over this time period occurred in the first three quarters, and on average, the percent raised per quarter was very low 4.4 percent in Q4 2013, 6.2 percent in Q1 2014, and 6.9 percent in Q2 2014. However, beginning in the third quarter of 2014, two items occurred - even fewer companies were attempting to raise funds via equity offerings, but the campaigns that were started became much more successful at raising funds. Compared to Q2 2014, in Q3 2014, the number of offerings dropped 67.6 percent (from 407 to 132), but the percent of the minimum target amount raised jumped to 23.4 percent (from 6.9 percent). The percent raised trended upward until Q4 2015 where it peaked at 35.4 percent and since then has trended downward to 13.6 percent in Q3 2016. 
Conversely, the number of initiated campaigns was highest in Q4 2013 at 1,729 and steadily declined to 6 in Q3 2016. Overall, the trend in the number of offerings aligns with the effective dates of Title II and Title III of the JOBS Act. Title II allowed accredited investors to invest in projects, and companies - hopeful to find new funding - rushed to seize the opportunity during the period covered by the first few quarters of our dataset. With little campaign success initially, fewer companies attempted to raise funds via an equity offering under Title II and perhaps some entrepreneurs delayed their offering until investment opportunities expanded to non-accredited investors through Title III (effective date of May 16, 2016).

\subsection{Regression Analysis}

The descriptive analysis illustrates that the percent raised varies by region, sector, and quarter-year; therefore, our estimation controls for these various effects when examining factors that are related to successful equity-based crowdfunding. Table 6 presents the Tobit regression results and marginal effects for two specifications.

Table 6. Tobit Regression Estimates \& Marginal Effects of Estimated Tobit Parameters

\begin{tabular}{|c|c|c|c|c|c|c|}
\hline \multirow[t]{4}{*}{ Variable } & \multicolumn{3}{|c|}{ Specification 1} & \multicolumn{3}{|c|}{ Specification 2} \\
\hline & Tobit & & & Tobit & & \\
\hline & $\begin{array}{c}\text { Regressi } \\
\text { on }\end{array}$ & & Marginal & $\begin{array}{c}\text { Regressi } \\
\text { on }\end{array}$ & & Marginal \\
\hline & Estimat & & Effect & Estimat & & Effect \\
\hline \multirow{3}{*}{ issuea } & es & & $\mathbf{s}$ & es & & $\mathbf{s}$ \\
\hline & -0.0227 & $* * *$ & -0.0042 & -0.0229 & $* * *$ & -0.0042 \\
\hline & $(0.0079)$ & & & $(0.0081)$ & & \\
\hline \multirow[t]{2}{*}{ w_owned } & -2.6546 & & -0.4872 & & & \\
\hline & $(2.7191)$ & & & & & \\
\hline \multirow[t]{2}{*}{ w_mngt } & & & & -2.2082 & & -0.4053 \\
\hline & & & & $(3.3185)$ & & \\
\hline \multirow{2}{*}{ r_equcap } & 17.4460 & $* * *$ & 3.2018 & 17.4718 & $* * *$ & 3.2066 \\
\hline & $(5.0925)$ & & & $(5.0909)$ & & \\
\hline \multirow{2}{*}{ tagline } & -71.4490 & $* * *$ & -13.1128 & -71.5513 & $* * *$ & -13.1318 \\
\hline & $(5.0685)$ & & & $(5.0925)$ & & \\
\hline \multirow[t]{2}{*}{ chgcpi } & -12.0002 & & -2.2023 & -12.1064 & & -2.2219 \\
\hline & (11.3132) & & & (11.3788) & & \\
\hline \multirow[t]{2}{*}{$\mathrm{sp} 500$} & 1.3795 & & 0.2532 & 1.3778 & & 0.2529 \\
\hline & $(1.2441)$ & & & $(1.2546)$ & & \\
\hline \multirow{2}{*}{ vixlevel } & -1.6730 & $* * *$ & -0.3070 & -1.6841 & $* * *$ & -0.3091 \\
\hline & $(0.5973)$ & & & $(0.6256)$ & & \\
\hline Region dummies & Yes & & & Yes & & \\
\hline Sector dummies & Yes & & & Yes & & \\
\hline Quarter-year dummies & Yes & & & Yes & & \\
\hline Number of observations & 3,222 & & & 3,222 & & \\
\hline No of left censored obs & 2,479 & & & 2,479 & & \\
\hline
\end{tabular}




\begin{tabular}{lcllll} 
Log-likelihood & $-4,811.05$ & \multicolumn{2}{c}{$-4,811.10$} & \\
Pseudo $\mathrm{R}^{2}$ & 0.0681 & \multicolumn{2}{c}{0681} & \\
\hline Standard errors robust & to sector-level & clusters & appear & in & parentheses. \\
$* * *$ denotes two-tailed significance level of $1 \%$. & & & &
\end{tabular}

Specification 1 examines if women-owned companies is related to percent raised whereas Specification 2 examines if women-managed companies is related to percent raised. Overall, the results for both specifications are similar, and for ease of presentation, Specification 1 results are discussed.

The statistically significant estimated coefficients on the company-specific variables indicate that the following are associated with a higher percentage of funds raised: (1) companies with lower minimum target amounts, (2) companies that report their equity capitalization and (3) companies that do not report a tagline. The minimum target amount result is consistent with our expectations and is consistent with previous findings in the literature (Block et al., 2018; Cordova et al., 2015; Lukkarinen et al., 2016). The result on reporting equity capitalization is also consistent with our expectation that more established companies are likely more attractive to investors. Of those companies that reported market capital, the average amount reported was $\$ 7.2$ million. The same cannot be said about our expectation for reporting a tagline. Because limited information is available to an investor when considering an equity crowdfunding investment decision, investors may look to description and tagline information to reduce information asymmetry. Our results are likely reflective of the quality of the text provided; the company taglines in our dataset vary considerably in the message disclosed. For example, there are companies that use vague taglines such as "Connecting Diagnostics." However, there are others that do a better job at informing potential investors about a project such as "A better pet shampoo with a lasting scent that helps wash away the homeless pet epidemic." The estimated marginal effect indicates that overall company taglines may not be well written and are putting companies at a disadvantage in terms of successfully raising funds. That is, given the other variables in our model, when a company tagline is reported, the percent raised is 13 percentages points lower, on average, compared to when a company tagline is not reported.

Finally, the estimated signs on the market-specific variables are consistent with our expectations, but only the VIX value is statistically significant. The results indicate that when the expected future volatility of the S\&P 500 Index is low, a higher percentage of funds are raised via equity crowdfunding efforts. This supports equity investments relative to allocations in other asset classes. 


\section{Conclusions \& Future Research}

This paper investigates the key determinants of online ECF campaign success. Our results are based on a comprehensive dataset comprised of 3,222 equity offers across 49 states and eight economic sectors. The study includes data on campaigns across 12 funding intermediaries. Our research is based on a unique dataset in a field with limited data availability. While Mamonov et al. (2017) provide a descriptive analysis of US equity Title II offers together with a detailed study of real estate campaigns and Mamonov and Malega (2019) examine success factors of Title II fundraising on one platform (Crowdfunder, $n=337$ ), our study reports a first in-depth analysis of Title II ECF in the US by examining more than 3,200 Title II offerings across 12 platforms.

Our findings regarding campaign success and significant factors such as minimum ask targets and reported equity capitalization, together with the negative effect of taglines, extend previous literature in this promising field of study. The sign and significance of the market sentiment VIX variable is also consistent with expectations, where equity investments are relatively attractive when low expected volatility conditions exist. This market variable significance provides offer timing implications for entrepreneurs seeking funding under ECF. In addition, the descriptive statistics herein lend depth to the understanding of equity crowdfunding in the U.S.

The results are based on the first three years of Title II ECF. To the extent that knowledge and familiarity with the crowdfunding process increases over time, future ECF offers may depend on new, additional factors. The findings described in this paper may or may not extend to Title III campaigns where non-accredited investors are allowed to participate. In addition, our study is constrained by the dataset characteristics and fields.

This study documents an unexpected negative result regarding offering taglines. We theorize that our tagline result is due to either the brevity of the tagline or the quality of the text provided. Limited research has examined the impact of investor sentiment toward equity crowdfunding offerings; therefore, more research is needed on the influence of the readability, tone, and overall sentiment of the equity crowdfunding written description and/or tagline on investors' investment behavior.

Language complexity, quality and positivity may be important components to the design of effective campaigns. Entrepreneurs, investors, and intermediaries each have an interest in reducing the informational asymmetry inherent in online ECF. Organized secondary markets are not yet available; therefore, all parties are bound by the long term nature of ECF. 


\section{REFERENCES}

1. Block, Joern, Lars Hornuf and Alexandra Moritz (2018), "Which Updates During an Equity Crowdfunding Campaign Increase Crowd Participation?”, Small Business Economics, Vol. 50, pp.3-27.

2. Colombo, Massimo G., Chiara Franzoni and Cristina Rossi-Lamastra (2015), "Internal Social Capital and the Attraction of Early Contributions in Crowdfunding", Entrepreneurship Theory and Practice, Vol. 39, No.1, pp.75-100.

3. Cordova, Alessandro, Johanna Dolci and Gianfranco Gianfrate (2015), "The Determinants of Crowdfunding Success: Evidence from Technology Projects", Procedia Social and Behavioral Sciences, Vol. 181, pp. 115-124.

4. Harkonen, Jirka (2014), "Crowdfunding and its Utilization for Startup Finance in Finland: Factors of a Successful Campaign” (Master's thesis), Lappeenranta University of Technology, School of Business, Lappeenranta, Finland,

http://doczz.net/doc/3531014/school-of-business-finance-master-s-thesis-jirkah\%C3\%A4rk\%C3\%B6nen, [Accessed on 2.22.2019]

5. Hayes, Suzanne (2017), “An Exploratory Study: Peer-to-Peer Online Lending”, The Southern Business and Economic Journal, 40(1), 33-55.

6. Horvat, Emoke-Agnes and Theodore Papamarkou (2017), "Gender Differences in Equity Crowdfunding", Proceedings of the Firth Conference on Human Computation and Crowdsourcing, Quebec City, Canada.

7. Lukkarinen, Anna, Jeffrey Teich, Hannele Wallenius, and Jyrki Wallenius (2016), "Success Drivers of Online Equity Crowdfunding Campaigns", Decision Support Systems, Vol. 87, pp. 26-38.

8. Malaga, Ross, Stanislav Mamonov and Janet Rosenblum (2018), “Gender Differences in Equity Crowdfunding: An Exploratory Analysis", International Journal of Gender and Entrepreneurship, https://doi.org/10.1108/IJGE-03-2018-0020, [Accessed

5.13.2019]

9. Mamonov, Stanislav and Ross Malaga (2019), "Success Factors in Title II Equity Crowdfunding in the United States", Venture Capital, Vol. 21, No. 2-3, pp. 223-241.

10. Mamonov, Stanislav and Ross Malaga (2019), "Success Factors in Title III Equity Crowdfunding in the United States" Electronic Commerce Research and Applications, Vol. 27, pp. 65-73.

11. Mamonov, Stanislav, Ross Malaga and Janet Rosenblum (2017), “An Exploratory Analysis of Title II Equity Crowdfunding Success”, Venture Capital, Vol. 19, No. 3, pp. 239-256.

12. Schwienbacher, Armin and Benjamin Larralde (2010), "Crowdfunding of Small Entrepreneurial Ventures”, SSRN Electronic Journal, Vol. 10, pp. 1-23, http://dx.doi.org/10.2139/ssrn.1699183

13. Szmigiera, M. (2019), Crowdfunding - Statistics Facts, https://www.statista.com/topics/1283/crowdfunding/, [Accessed 1.28.2020] 
14. United States Securities and Exchange Commission (2016), Spotlight on Jumpstart Our Business Startups, https://www.sec.gov/spotlight/jobs-act.shtml, [Accessed 2.22.2019]

15. United States Securities and Exchange Commission. SEC. (2019), Report to the Commission: Regulation Crowdfunding, https://www.sec.gov/regulationcrowdfunding-2019_0.pdf, [Accessed 9.7.2019]

16. Vismara, Silvio (2016), "Equity Retention and Social Network Theory in Equity Crowdfunding”, Small Business Economics, Vol. 46, pp. 579-590.

17. Wooldridge, Jeffrey M. (2002), Econometric Analysis of Cross Section and Panel Data, The MIT Press, Cambridge, M.A.

18. Yan, Sijia (2015), "Which Signaling Factors Facilitate the Success Probability of Equity Crowdfunding? (Bachelor's Thesis), University of Twente, The Netherlands, https://essay.utwente.nl/68537/1/Yan_BA_MB.pdf, [Accessed on 9.7.201 